\title{
Regulation of urocortin I and its related peptide urocortin II by inflammatory and oxidative stresses in HL-1 cardiomyocytes
}

\author{
Keiichi Ikeda ${ }^{1}$, Katsuyoshi Tojo ${ }^{2}$, Yuri Inada ${ }^{2}$, Yuko Takada ${ }^{2}$, Masaya Sakamoto ${ }^{2}$, May Lam ${ }^{3}$, \\ William C Claycomb ${ }^{3}$ and Naoko Tajima ${ }^{2}$ \\ ${ }^{1}$ Department of Pharmacology and ${ }^{2}$ Division of Diabetes and Endocrinology, Department of Internal Medicine, the Jikei University School of Medicine, Tokyo 105-8461, Japan \\ ${ }^{3}$ Department of Biochemistry and Molecular Biology, Health Sciences Center, Louisiana State University, New Orleans, Louisiana 70112, USA \\ (Correspondence should be addressed to K Ikeda; Email: ikedak@jikei.ac.jp)
}

\begin{abstract}
Despite our knowledge on the regulation of urocortin (Ucn) I and its related peptides in the heart, the possible involvement of cardiovascular stress substances, such as cytokines or angiotensin II (Ang II), on this regulation remains to be fully elucidated. We therefore evaluated the potential role of cardiovascular stress substances on the regulation of the Ucn-corticotropin-releasing hormone $(\mathrm{CRH})$ receptor system in $\mathrm{HL}-1$ cardiomyocytes using a Ucn I-specific RIA, conventional reverse transcription-PCR (RT-PCR) and quantitative real-time RT-PCR. Ucn I mRNA levels were shown to be up-regulated by lipopolysaccarides (LPS), tumor necrosis factor- $\alpha$ (TNF- $\alpha$ ), Ang II, $\mathrm{H}_{2} \mathrm{O}_{2}$, and pyrrolidinedithiocarbamate (PDTC). The LPS- and Ang II-induced increase in Ucn I mRNA levels was abolished by tempol. In addition, the secretion of Ucn I from HL-1 cardiomyocytes was stimulated by LPS and TNF- $\alpha$. On the contrary, Ucn II mRNA was increased by TNF- $\alpha$ alone and Ang II with tempol, and the TNF- $\alpha$-induced increase in Ucn II mRNA was abolished by erythromycin and PDTC. These results suggested that Ucn I mRNA may be up-regulated by oxidative stress, whereas Ucn II mRNA may be up-regulated by the activated nuclear factor- $\kappa \mathrm{B}$, i.e. inflammatory stress. $\mathrm{CRH}-\mathrm{R} 2 \mathrm{mRNA}$ may be negatively regulated by the increase in expression of Ucn I and/or Ucn II mRNA. In conclusion, the Ucn-CRH receptor system may be regulated by two major forms of cardiac stresses, i.e. oxidative and inflammatory stress, and may play a critical role in cardiac stress adaptation in heart diseases.
\end{abstract}

Journal of Molecular Endocrinology (2009) 42, 479-489

\section{Introduction}

Urocortin (murine urocortin: Ucn, human urocortin: UCN) I, Ucn II, and Ucn III, the members of corticotropin-releasing hormone (CRH)-related peptides, have various actions on the cardiovascular system via cAMP-dependent pathways and the extracellularly regulated kinase $1 / 2$ pathway (Ikeda et al. 1998, 2002, 2005a, Brar et al. 2004a, Honjo et al. 2006). We previously reported the pathophysiological involvement of UCN I in cardiomyopathies (Ikeda et al. 2003), in which a patient's plasma concentration of tumor necrosis factor (TNF)- $\alpha$ increased (Matsumori et al. 1994). TNF- $\alpha$ can produce various deleterious effects when expressed in large amounts and it is produced in the heart by both cardiomyocytes and resident macrophages under conditions of cardiac stress (Sarzi-Puttini et al. 2005). In addition, Ucn I was up-regulated by TNF- $\alpha$ in human umbilical vein endothelial cells (Honjo et al. 2006), and, in turn, CRH type 2 receptor (CRH-R2) was down-regulated by lipopolysaccarides
(LPS) and TNF- $\alpha$ in the mouse heart (Ikeda et al. 1998, Coste et al. 2001). Because CRH-R2 was also downregulated by Ucn I in mouse cardiomyocytes (Heldwein et al. 1997, Coste et al. 2001) and in the mouse heart (Asaba et al. 2000), we hypothesize that LPS and TNF- $\alpha$ may stimulate the release of endogenous ligand(s) for CRH-R2, such as CRH, Ucn I, Ucn II, and/or Ucn III, from the heart. Also, we previously demonstrated that LPS and TNF- $\alpha$ stimulated the secretion of Ucn I, but not of CRH from neonatal rat cardiac myocytes and non-cardiac myocytes (Ikeda et al. 2001). These findings suggest that Ucn I and its related peptides may be regulated by inflammatory cytokines, such as LPS and TNF- $\alpha$, and may play a pathophysiological role in the diseased heart because CRH-R2 signaling in the heart may be very important for adaptation to cardiac stress in pathological conditions (Coste et al. 2000). Ucn I may be regulated in response to oxidative stress, thereby exerting a vasoprotective role against the oxidative stress caused by angiotensin II (Ang II) in HUVECs (Honjo et al. 2006). We hypothesized that Ucn I and its 
related peptides may be regulated by inflammatory and/or oxidative stress(es) in the diseased heart. Therefore, the present study aims to evaluate the regulation of Ucn I and Ucn II in relation to inflammatory and oxidative stress.

\section{Materials and methods}

\section{Cell culture}

HL-1 cardiomyocytes, an immortalized cardiomyocyte cell line derived from mouse atria (Claycomb et al. 1998), were cultured as previously described (Ikeda et al. 2005b) with slight modification. Briefly, cells were plated in $10 \mathrm{~cm}$ culture dishes pre-coated with $0.02 \%$ Bacto gelatin (Becton, Dickinson, and Company, Franklin Lakes, NJ, USA) and $5 \mu \mathrm{g} / \mathrm{ml}$ fibronectin (Sigma-Aldrich Inc., St Louis, MO, USA) or in fibronectin-pre-coated $10 \mathrm{~cm}$ culture dishes (BD BioCoat, Becton, Dickinson, and Company) and cultured until cells reached confluence in Claycomb Medium (SAFC Biosciences, Lenexa, KS, USA) supplemented with $10 \%$ fetal bovine serum (FBS, Sigma-Aldrich Inc.), $0 \cdot 1 \mathrm{mM}$ norepinephrine (Sigma-Aldrich Inc.), $1 \%$ L-GlutaMAX (Invitrogen Corp.), and antibiotics $(100 \mathrm{u} / \mathrm{ml}$ penicillin $\mathrm{G}$ and $10 \mu \mathrm{g} / \mathrm{ml}$ streptomycin). The cells were then removed by trypsinization and passed into another $10 \mathrm{~cm}$ culture dish, $6 \mathrm{~cm}$ culture dish, 12-well plate $\left(3 \cdot 0 \times 10^{5}\right.$ cells/well), or a 6 -well plate $\left(6 \cdot 0 \times 10^{5}\right.$ cells/well $)$ pre-coated with fibronectin/ gelatin. Cells were cultured in FBS and norepinephrine-free Claycomb Medium supplemented with 1\% L-GlutaMAX and antibiotics for $24 \mathrm{~h}$ prior to each experiment except when cells were used for conventional reverse transcription-PCR (RT-PCR).

\section{cDNA preparation and conventional RT-PCR}

Total RNA was extracted from HL-1 cardiomyocytes (at confluence in a $6 \mathrm{~cm}$ culture dish) by the acidguanidium-phenol-chloroform (AGPC) method with $1 \mathrm{ml}$ /dish TRIzol Reagent (Invitrogen Corp.) and treated with DNase I (Takara Bio Inc., Otsu, Japan). Three micrograms of total RNA were used to synthesize cDNA with SuperScript III First-Strand Synthesis System (Invitrogen Corp.) after contamination of genomic DNA was ruled out by 50 cycle PCR with $\beta$-actin primers (shown in Table 1, estimated amplicon size: $510 \mathrm{bp}$ ). PCR was performed using Takara taq hot start version (Takara Bio Inc.) and primers specific for CRH-R1, CRH-R2 (Brar et al. 2004a), Ucn I, Ucn II (Li et al. 2003), and Ucn III (GenBank accession No. AF361944, designed by the Primer3 software (Rozen \& Skaletsky 2000), estimated amplicon size: $254 \mathrm{bp})$. PCR was performed on cDNA from
HL-1 cardiomyocytes, with conditions consisting of initial denaturation at $94^{\circ} \mathrm{C}$ for $4 \mathrm{~min}$, 3-step PCR cycles (CRH-R1, CRH-R2, Ucn I, and Ucn II, 35 cycles; Ucn III, 36 cycles; $\beta$-actin, 25 cycles: denaturation at $94{ }^{\circ} \mathrm{C}$ for $1 \mathrm{~min}$, annealing at the temperatures shown in Table 1 for $1 \mathrm{~min}$, and extension at $72^{\circ} \mathrm{C}$ for $1 \mathrm{~min}$ ), with a final extension at $72{ }^{\circ} \mathrm{C}$ for $7 \mathrm{~min}$. As a positive control, cDNA from mouse brain (mouse brain QUICK-Clone cDNA, Clontech Laboratories, Inc., Mountain View, CA, USA) was used. In addition, expression of CRH-R1/R2 and Ucn mRNA in the mouse heart was also evaluated using $0 \cdot 1 \mathrm{ng}$ cDNA/ reaction (Mouse Heart QUICK-Clone cDNA, Clontech Laboratories, Inc.). Primer sequences and annealing temperatures are summarized in Table 1.

\section{Measurement of Ucn I levels secreted from HL-1 cardiomyocytes}

To evaluate secretion of Ucn I from HL-1 cardiomyocytes, cells were cultured in 6-well plates and stimulated with LPS (1 $\mathrm{ng} / \mathrm{ml}$, Sigma-Aldrich Inc.), TNF- $\alpha$ (10 ng/ml, Sigma-Aldrich Inc.) or Ang II $\left(10^{-7}\right.$ mol/1, Peptide Institute, Inc., Osaka, Japan) for 3, 6,

Table 1 Primers for conventional reverse transcription-PCR

Primer sequences and annealing temperatures

\begin{tabular}{|c|c|}
\hline \multicolumn{2}{|l|}{$C R H-R 1$} \\
\hline $\begin{array}{l}\text { Annealing } \\
\text { temperature }\end{array}$ & $62.9^{\circ} \mathrm{C}$ \\
\hline Forward & 5'-GGTGTGCCTTTCCCСАTCATT-3' \\
\hline Reverse & $5^{\prime}$-CAACATGTAGGTGATGCCCAG-3' \\
\hline \multicolumn{2}{|r|}{ 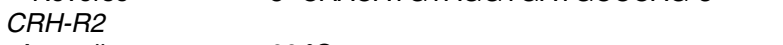 } \\
\hline $\begin{array}{l}\text { Annealing } \\
\text { temperature }\end{array}$ & $60^{\circ} \mathrm{C}$ \\
\hline Forward & 5'-GGCAAGGAAGCTGGTGATTTG-3' \\
\hline Reverse & 5'-GGCGTGGTGGTCCTGCCAGCG-3' \\
\hline \multicolumn{2}{|r|}{ - } \\
\hline $\begin{array}{l}\text { Annealing } \\
\text { temperature }\end{array}$ & $68^{\circ} \mathrm{C}$ \\
\hline Forward & 5'-CTTCGCCCGGAGAGCAGCCAGTG-3' \\
\hline Reverse & 5'-GCGTTCCAGCCCCGGGGTAGGTAA-3' \\
\hline \multicolumn{2}{|r|}{ 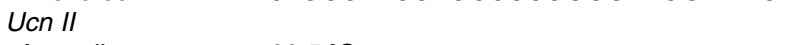 } \\
\hline $\begin{array}{l}\text { Annealing } \\
\text { temperature }\end{array}$ & $66.5^{\circ} \mathrm{C}$ \\
\hline Forward & $5^{\prime}$-GGCCGCCGCTGAGACTGAA-3' \\
\hline Reverse & 5'-GGCCTGTGGACCTTAGATGGACTT-3' \\
\hline \multicolumn{2}{|r|}{ 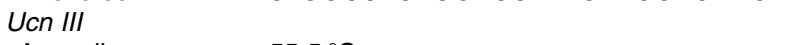 } \\
\hline $\begin{array}{l}\text { Annealing } \\
\text { temperature }\end{array}$ & $55.5^{\circ} \mathrm{C}$ \\
\hline Forward & 5'-CAAGCCTCTCCCACAAGTTC- $3^{\prime}$ \\
\hline Reverse & 5'-TGCCTGGGATTGGTATCTGT-3' \\
\hline$\beta$-actin & \\
\hline $\begin{array}{l}\text { Annealing } \\
\text { temperature }\end{array}$ & $54 \cdot 4^{\circ} \mathrm{C}$ \\
\hline $\begin{array}{l}\text { Forward } \\
\text { Reverse }\end{array}$ & $\begin{array}{l}\text { 5'-GACTACCTCATGAAGATCCT-3' } \\
5^{\prime} \text {-CCACATCTGCTGGAAGGTGG-3' }\end{array}$ \\
\hline
\end{tabular}


Table 2 Primers for quantitative real-time reverse transcription-PCR

\section{Primer sequences}

CRH-R2

Forward

Reverse

Ucn I

Forward

Reverse

Ucn II

Forward

Reverse

GAPDH

Forward

Reverse

12, and $24 \mathrm{~h}$. The culture medium was collected and stored at $-80^{\circ} \mathrm{C}$ until measurement of Ucn I by Ucn I-specific RIA kit (Pheonix Pharmaceutical, Inc., Belmont, CA, USA). The total amount of protein from the HL-1 cardiomyocytes in each well was extracted by the M-PER Mammalian Protein Extraction Reagent (Pierce Biotechnology, Inc., Rockford, IL, USA) and measured using a bicinchoninic acid Protein Assay Reagent Kit (Pierce Biotechnology, Inc.) according to the manufacturer's protocol (Smith et al. 1985). Secreted Ucn I was normalized against the total cellular protein of the HL-1 cardiomyocytes in each well. Data are presented as $\mathrm{pmol} / \mathrm{mg}$ protein.

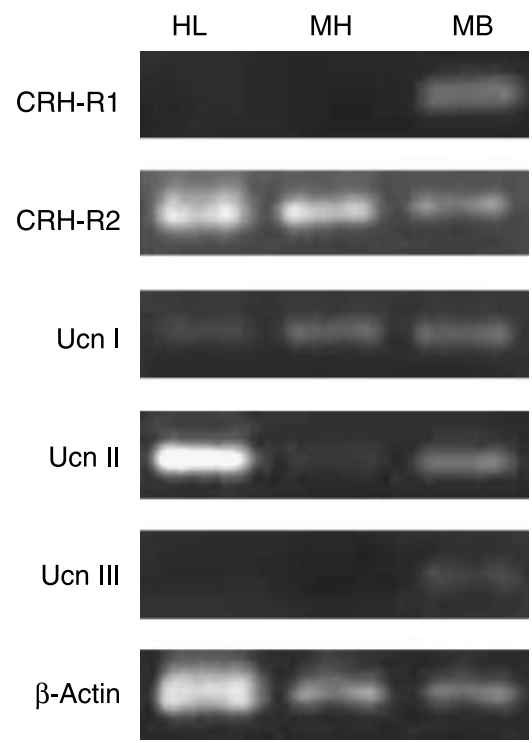

Figure 1 Expression of CRH-R1, CRH-R2, Ucn I, Ucn II, Ucn III, and $\beta$-actin mRNA in $\mathrm{HL}-1$ cardiomyoyctes by RT-PCR. $\mathrm{CRH}-\mathrm{R} 2$, Ucn I, and Ucn II mRNAs, but not CRH-R1 and Ucn III mRNAs, were expressed in $\mathrm{HL}-1$ cardiomyocytes. $\mathrm{HL}, \mathrm{HL}-1$ cardiomyocytes cDNA, MH, mouse heart QUICK-clone cDNA, MB, mouse brain QUICK-clone cDNA.

\section{cDNA preparation and quantitative real-time RT-PCR}

HL-1 cardiomyocytes cultured in 6-well plates were stimulated with or without LPS $(1 \mathrm{ng} / \mathrm{ml})$ and TNF- $\alpha$ $(10 \mathrm{ng} / \mathrm{ml})$ for $3,6,12$, and $24 \mathrm{~h}$. The HL-1
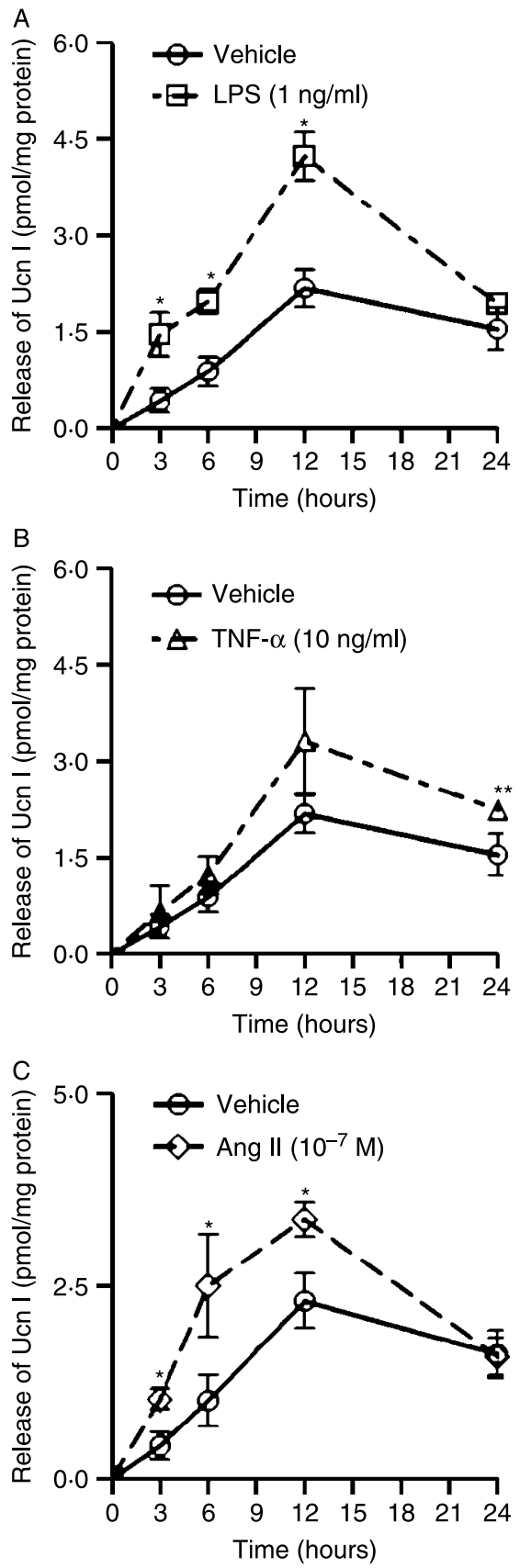

Figure 2 The influence on the secretion of Ucn I from $\mathrm{HL}-1$ cardiomyocytes by cytokines LPS (A) and TNF- $\alpha$ (B) and Ang II (C). Secretion of Ucn I was significantly increased by LPS, TNF- $\alpha$, and Ang II. Data were represented as mean \pm S.D. ${ }^{\star} P<0.01$ versus vehicle, ${ }^{\star \star} P<0.05$ versus vehicle. 

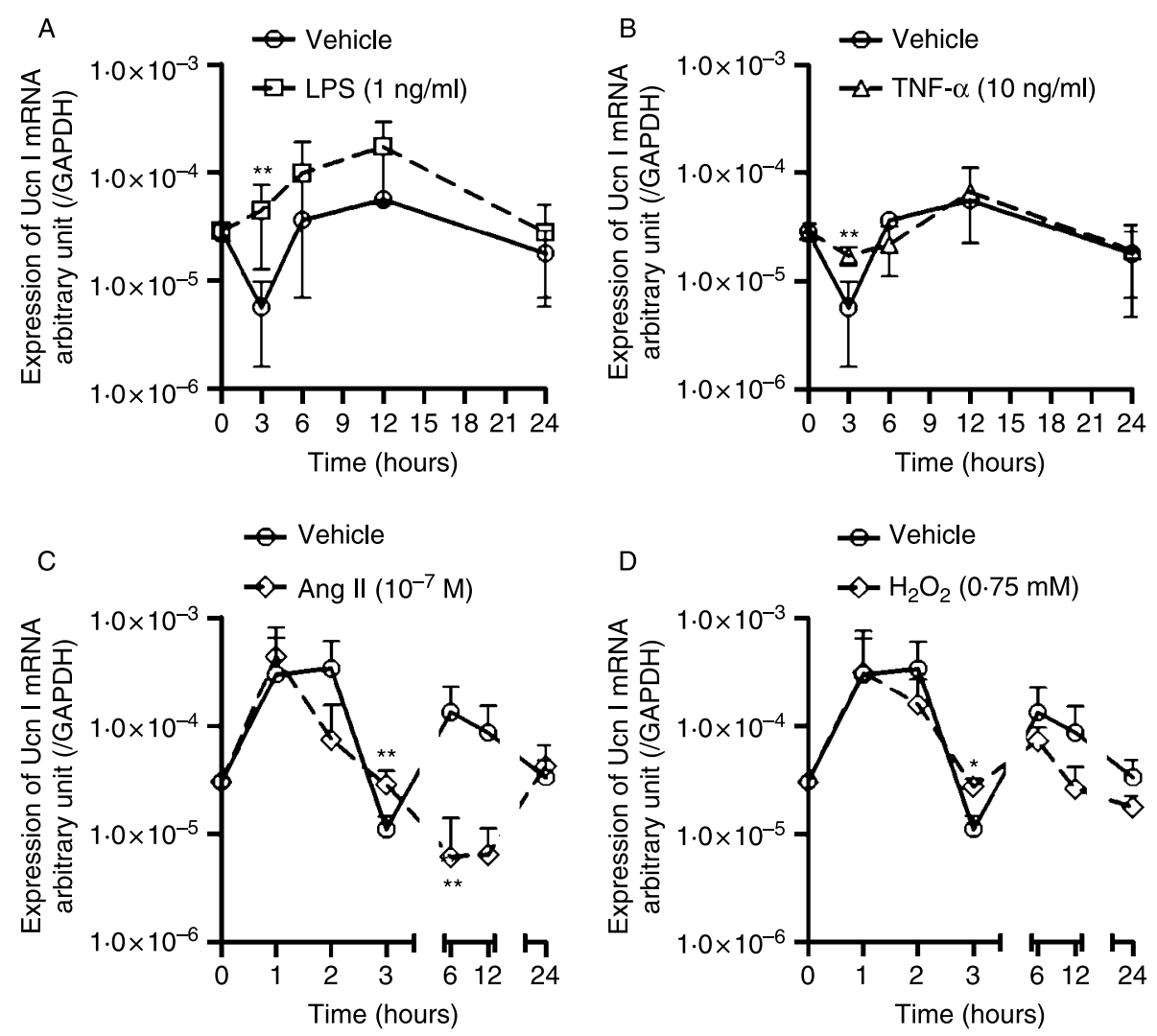

Figure 3 Time-dependent expression of Ucn I mRNA stimulated by LPS (A), TNF- $\alpha$ (B), Ang II (C), and $\mathrm{H}_{2} \mathrm{O}_{2}$ (D). Ucn I mRNA was significantly increased by LPS, TNF- $\alpha$, Ang II, and $\mathrm{H}_{2} \mathrm{O}_{2}$ at $3 \mathrm{~h}$. And, thereafter, Ang II significantly suppressed Ucn I mRNA. ${ }^{\star} P<0.01$ versus vehicle, ${ }^{\star \star} P<0.05$ versus vehicle. Data are presented as the mean \pm s.D.

cardiomyocytes were then stimulated by LPS $(0 \cdot 01-$ $10 \mathrm{ng} / \mathrm{ml})$, TNF- $\alpha(0 \cdot 1-100 \mathrm{ng} / \mathrm{ml})$, and Ang II $\left(10^{-11}\right.$, $10^{-9}, 10^{-7}$, and $10^{-6} \mathrm{~mol} / \mathrm{l}$ ) for $3 \mathrm{~h}$ with or without a

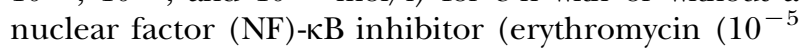
mol/l, Sigma-Aldrich Inc.; Desaki et al. 2004) or ammonium pyrrolidinedithiocarbamate (PDTC, $10^{-4}$ mol/1, Sigma-Aldrich Inc.; Sherman et al. 1993, Boyd et al. 2006). To evaluate the involvement of oxidative stress on the expression of Ucn I and Ucn II mRNAs, we used $\mathrm{H}_{2} \mathrm{O}_{2}$ (Nakalai Tesque, Inc., Kyoto, Japan) at $0.5,0.75$ (Saito et al. 2001), and $1 \mathrm{mmol} / \mathrm{l}$ and the superoxide dismutase mimetic, 4-hydroxy-2, 2, 6, 6-tetramethylpiperidine-1-oxyl (tempol, $10^{-4} \mathrm{~mol} / \mathrm{l}$, Merck KGaA (Calbiochem), Darmstadt, Germany; Sakai et al. 2007). After washing twice with cold PBS, the cells were lysed by TRIzol reagent $(1 \mathrm{ml} /$ well $)$ and stored at $-80^{\circ} \mathrm{C}$ until RNA extraction. Total RNA was extracted by the AGPC method and treated with DNase I until genomic DNA was no longer detected by 50 cycle PCR as described. Then cDNA was synthesized by primescript RT reagent kit (Takara Bio, Inc.) with oligo dT primers. Real-time PCR was performed on a Thermal Cycler Dice (Takara Bio, Inc) with SYBR premix Ex
Taq/Taq II (Takara Bio, Inc.) according to the manufacturer's protocols. The specific primers against mouse CRH-R2, Ucn I, Ucn II, and glyceraldehyde3-phosphate-dehydrogenase (GAPDH) are summarized in Table 2. The real-time PCR was performed with conditions consisting of initial denaturation at $94{ }^{\circ} \mathrm{C}$ for $10 \mathrm{~s}$, 2-step PCR cycles $\left(50\right.$ cycles, denaturation at $95^{\circ} \mathrm{C}$ for $5 \mathrm{~s}$, annealing and detection step at $60^{\circ} \mathrm{C}$ for $30 \mathrm{~s}$ ), and the confirmation step of quality of PCR products by the dissociation curve (denaturation at $95{ }^{\circ} \mathrm{C}$ for $15 \mathrm{~s}$ followed by step-up elevation of temperature from 60 to $95^{\circ} \mathrm{C}$ by $0.5^{\circ} \mathrm{C}$ for every $30 \mathrm{~s}$ ). Quantitative data were analyzed by the $2^{-\Delta \Delta C_{\mathrm{t}}}$ method (Livak \& Schmittgen 2001), using the 2nd derivative curve of the amplification plots (Thermal Cycler Dice Real Time System TP800 software version 2.00B, Takara Bio, Inc.) and normalized against GAPDH cycle thresholds.

\section{Statistical analysis}

Statistical analysis was performed using ANOVA followed by a post hoc test for between-group comparison (StatView 5.0, SAS Institute, Inc., Cary, NC, USA). 

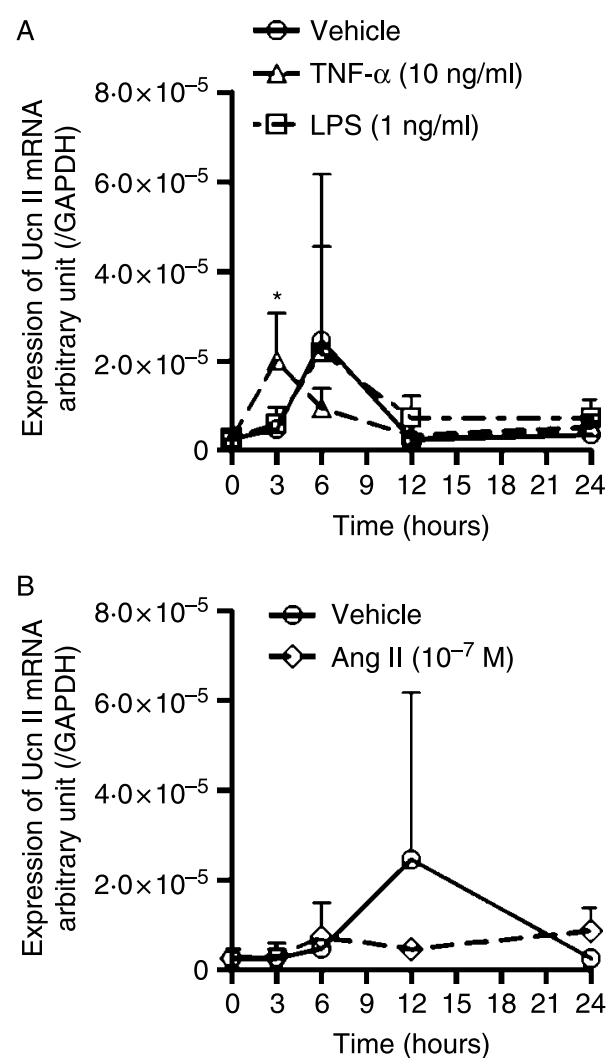

Figure 4 Time-dependent expression of Ucn II mRNA stimulated by LPS and TNF- $\alpha(\mathrm{A})$ and Ang II (B). ${ }^{*} P<0.01$ versus vehicle. TNF- $\alpha$ significantly increased Ucn II mRNA at $3 \mathrm{~h}$ but LPS and Ang II did not exert significant actions on expression of Ucn II mRNA. Data are presented as the mean \pm s.D.

$P$ values $<0.05$ were considered to indicate statistical significance, and all data were expressed as the means \pm s.D.

\section{Results}

\section{Expression of mouse Ucn I and its related peptides in HL-1 cardiomyocytes}

RT-PCR revealed that CRH-R2, Ucn I, and Ucn II mRNA were expressed in both HL-1 cardiomyocytes and the mouse heart (Fig. 1). However, CRH-R1 and Ucn III mRNA were not expressed in this cardiomyocyte cell line and the mouse heart (Fig. 1).

\section{Secretion of Ucn I by HL-1 cardiomyocytes stimulated with LPS, TNF- $\alpha$, and Ang II}

Ucn I-like immunoreactivity (Ucn I-LI) increased in the culture medium of HL-1 cardiomyocytes in a timedependent manner. The secretion of Ucn I, as detected by RIA, significantly increased in response to LPS $(3,6$,
$12 \mathrm{~h}: P<0.01$ versus vehicle, Fig. $2 \mathrm{~A})$ and to TNF- $\alpha$ (24 h: $P<0.05$ versus vehicle, Fig. 2B). In addition, secretion of Ucn I-LI from HL-1 cardiomyocytes was also significantly increased by Ang II $(3,6,12 \mathrm{~h}: P<0 \cdot 01$ versus vehicle, Fig. 2C).

\section{Real-time RT-PCR detection of mouse Ucn I, Ucn II, and CRH-R2 mRNA}

Real-time RT-PCR demonstrated that both LPS and TNF- $\alpha$ significantly increased Ucn I mRNA expression at $3 \mathrm{~h}$ (Fig. 3A and B). At $3 \mathrm{~h}$, expression of Ucn II mRNA was significantly increased by TNF- $\alpha$, but not by LPS (Fig. 4A). Expression of Ucn I mRNA increased in a dose-dependent manner in response to LPS at $3 \mathrm{~h}$ (Fig. 5A). On the contrary, expression of Ucn II mRNA was not significantly affected by LPS at $3 \mathrm{~h}$ (Fig. 5E). TNF- $\alpha$, on the other hand, increased expression of both Ucn I and Ucn II mRNA dose dependently (Fig. 5B and $\mathrm{F}$ ). Furthermore, Ang II and $\mathrm{H}_{2} \mathrm{O}_{2}$ significantly stimulate the expression of Ucn I mRNA compared with vehicle at $3 \mathrm{~h}$ (Fig. $3 \mathrm{C}$ and $\mathrm{D}$ ). This increase in Ucn I mRNA occurs in a dose-dependent manner at $3 \mathrm{~h}$ (Fig. 5C and D). But Ang II suppressed the expression of Ucn I mRNA at 6 and $12 \mathrm{~h}$ (Fig. 3C). On the contrary, Ang II did not affect expression of Ucn II mRNA (Fig. 4B). Expression of CRH-R2 mRNA seemed to be decreased by the combined effects of the Ucn I and Ucn II induced by LPS and TNF- $\alpha$ at 3 and $12 \mathrm{~h}$ (Fig. 6A and B). Erythromycin ameliorated the LPS-induced increase in Ucn I mRNA. However, erythromycin did not affect the TNF- $\alpha$-induced increase in Ucn I mRNA (Fig. 7A and B). PDTC alone significantly increased Ucn I mRNA but exerted no significant effects on TNF$\alpha$-induced increase in Ucn I mRNA (Fig. 7C and D). And the increase in the expression of Ucn I mRNA by PDTC and LPS seemed to be additive to that of LPS but the difference did not reach statistical significance (Fig. 7C). The TNF- $\alpha$-induced increase in Ucn II mRNA was abolished by erythromycin and PDTC (Fig. 7E). Tempol, an antioxidant, abolished the LPS-induced increase in Ucn I mRNA, whereas tempol significantly potentiated the action of the TNF- $\alpha$-induced increase in Ucn I mRNA (Fig. 8A and B). Furthermore, the Ang II-induced increase in Ucn I mRNA was abolished by tempol, whereas Ucn II mRNA was inversely regulated by Ang II and tempol (Fig. 8C and E). In addition, tempol abolished the PDTC-induced increase in Ucn I mRNA (Fig. 8D).

\section{Discussion}

In the present study, we demonstrate that HL-1 cardiomyocytes express Ucn I, Ucn II, and CRH-R2, indicating that this cardiomyocyte cell line is a useful 

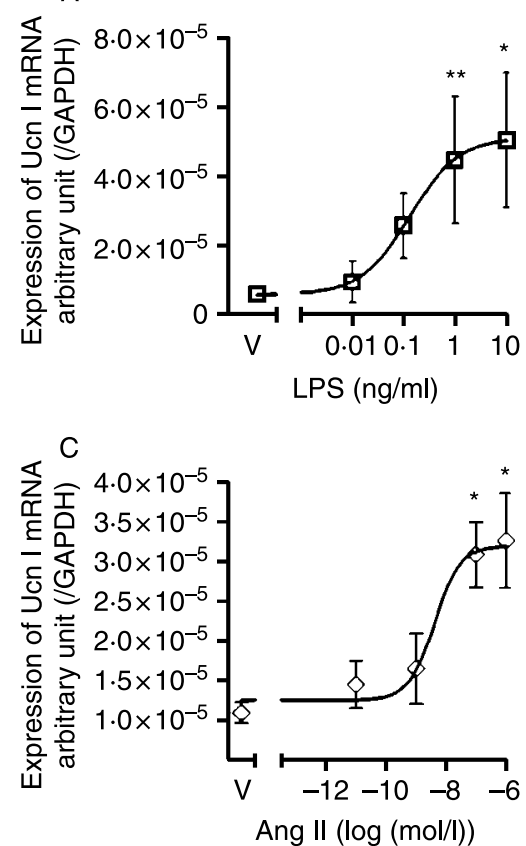

E

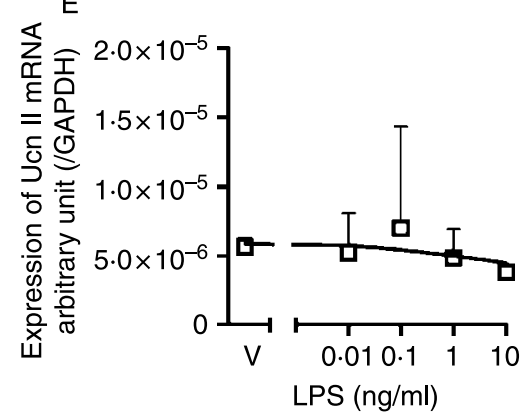

B
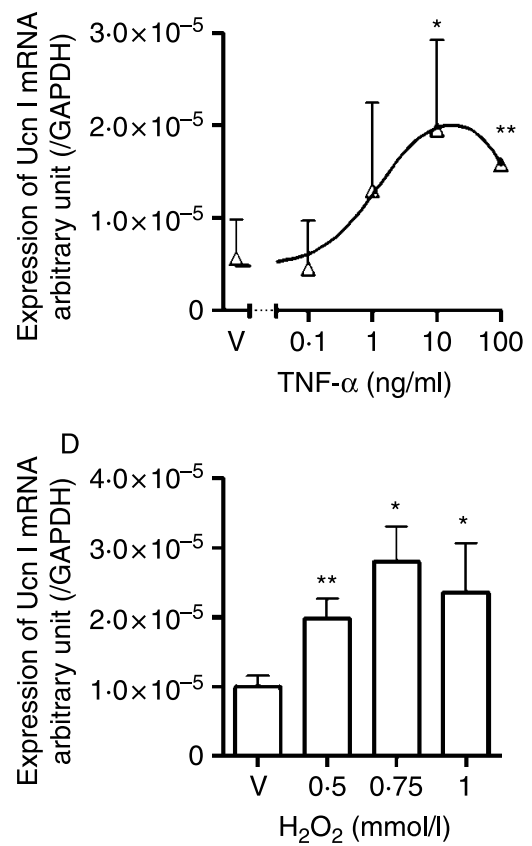

$\mathrm{F}$

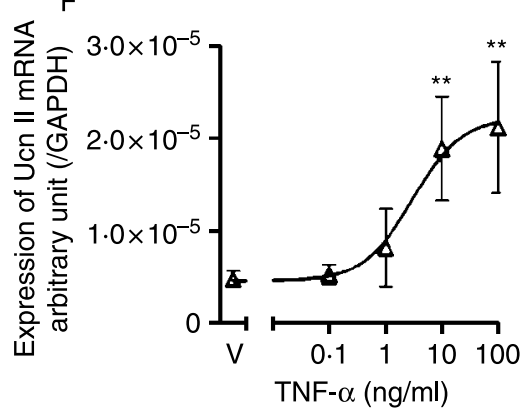

Figure 5 Dose-dependent expression of Ucn I and Ucn II mRNA by LPS (Ucn I (A), Ucn II (E)) and by TNF- $\alpha$ (Ucn I (B), Ucn II (F)) and expression of Ucn I mRNA by Ang II (C) and $\mathrm{H}_{2} \mathrm{O}_{2}$ (D) in $\mathrm{HL}-1$ cardiomyocytes at $3 \mathrm{~h}$. Expression of Ucn I mRNA following stimulation by LPS, TNF- $\alpha$, Ang II, and $\mathrm{H}_{2} \mathrm{O}_{2}$, and Ucn II mRNA by TNF- $\alpha$ were generally increased in a dose-dependent manner. Data are presented as the mean \pm s.D. ${ }^{*} P<0.01$ versus vehicle, ${ }^{\star \star} P<0.05$ versus vehicle.

model for investigating the Ucn-CRH receptor system (Ikeda et al. 2005a). Although CRH-R1 is involved in anxiety and neuroendocrine stress and CRH-R1 and Ucn III were reported to be expressed in the human heart (Kimura et al. 2002, Takahashi et al. 2004), neither CRH-R1 nor Ucn III mRNA was expressed in the HL-1 mouse atrial cardiomyocyte cell line. These data are supported by previous studies using rat and mouse cardiomyocytes (Brar et al. 2004b, Ikeda et al. 2005a). Therefore, Ucns act through CRH-R2, the main mediator of the stress response in cardiomyocytes (Coste et al. 2000, Pañeda et al. 2005), rather than through CRH-R1. This suggests that the autocrine stress adaptation system is mediated by endogenous Ucn I,
Ucn II, and CRH-R2 in HL-1 cardiomyocytes and by exogenous CRH-R2 ligands.

Previous studies demonstrated an increase in the expression of Ucn I in target regions of inflammation in diseases involving TNF- $\alpha$ (Uzuki et al. 2001, Ikeda et al. 2003, Saruta et al. 2004). In addition, a recent study showed that the expression of Ucn II mRNA was increased in mucosal samples of patients with inflammatory bowel disease, and in human intestinal xenografts following exposure to Clostridium difficile toxin A (Moss et al. 2007), an activator of NF-KB (Jefferson et al. 1999), indicating that the regulation of Ucn II may be involved in the NF- $\kappa$ B pathway. Our present results showed that LPS, Ang II, and $\mathrm{H}_{2} \mathrm{O}_{2}$ 

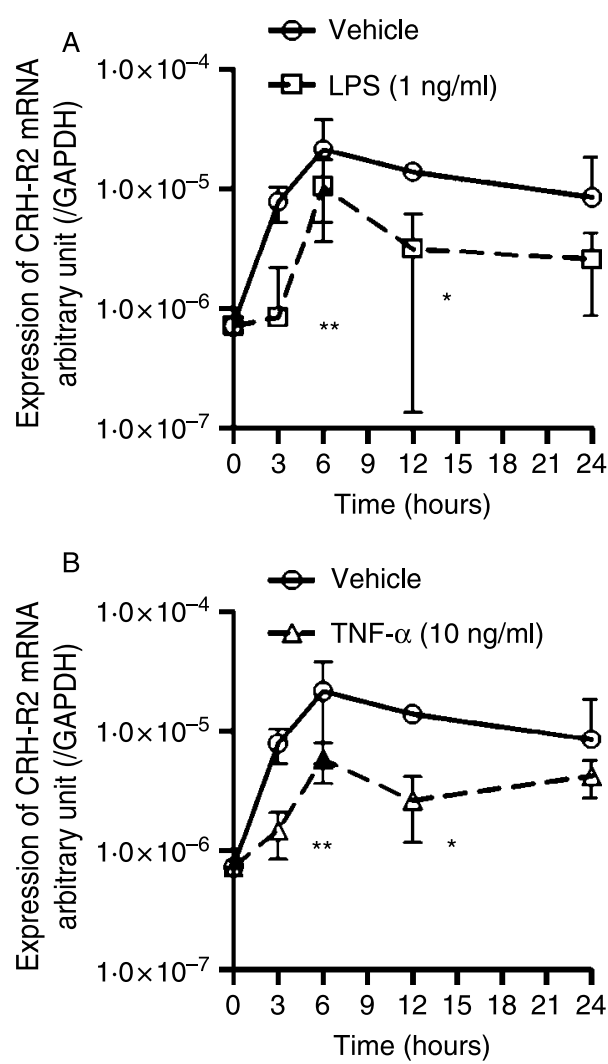

Figure 6 Time-dependent expression of $\mathrm{CRH}-\mathrm{R} 2$ mRNA stimulated by LPS (A) and TNF- $\alpha$ (B). LPS and TNF- $\alpha$ significantly suppressed the expression of $\mathrm{CRH}-\mathrm{R} 2 \mathrm{mRNA}$ at $3 \mathrm{~h}$ and at $12 \mathrm{~h}$. LPS and TNF- $\alpha$ also tended to suppressed CRH-R2 mRNA at $6 \mathrm{~h}$ and $24 \mathrm{~h}$, but differences to vehicle did not reach statistical significance. ${ }^{\star} P<0.01$ versus vehicle, ${ }^{\star \star} P<0.05$ versus vehicle. Data are presented as the mean \pm s.D.

individually enhanced the expression of Ucn I mRNA in as well as the secretion of Ucn I from HL-1 cardiomyocytes, and that these effects were abolished by tempol. This increase in Ucn I mRNA by LPS and Ang II was abolished by antioxidants such as erythromycin (Miyachi et al. 1986) and tempol. Although HL-1 cardiomyocytes expressed toll-like receptor (TLR; Boyd et al. 2006), the present results showed that the actions of LPS may not be the action via the TLR signaling because of the absence of LPS-binding protein, which enhances biological action of LPS (Hailman et al. 1994), in stimulation medium and abolishment of the action of LPS on expression of Ucn I mRNA by antioxidant. These results, taken in combination with the demonstration that LPS and Ang II cause oxidative stress (Honjo et al. 2006, Yuan et al. 2009), strongly suggests that Ucn I may be positively regulated by oxidative stress. Ang II markedly increased the secretion of Ucn I up to $12 \mathrm{~h}$, with a temporal increase of Ucn I mRNA followed by suppression. The increase in Ucn I levels in the culture medium may result in an increase in intracellular cAMP (Ikeda et al. 1998), leading to the induction of a family of cAMP-responsive nuclear factors, including inducible cAMP early repressor (Sassone-Corsi 1998). Consequently, due to the presence of a cAMP responsive element (CRE) in the Ucn I promoter region (Zhao et al. 1998), the decrease in the expression of Ucn I mRNA may be attributed to the binding of inducible cAMP early repressor to the CRE after an initial increase in the expression of Ucn I mRNA. A return to basal Ucn I levels in the culture medium with LPS and Ang II may be, at least in part, due to the endocytosis of Ucn I (Tu et al. 2007). But further studies are required to clarify these results. In addition, PDTC alone enhanced the expression of Ucn I mRNA. PDTC is known as an inhibitor of nitric oxide synthase (NOS; Sherman et al. 1993), suggesting that up-regulation of Ucn I mRNA may be caused by increased oxidative stress secondary to inhibition of NOS by PDTC. A demonstration of an inhibition of PDTC-induced increase in Ucn I mRNA by tempol will support this hypothesis. But the precise mechanism of the regulation of Ucn I mRNA by TNF- $\alpha$ is not known. The expression of Ucn II mRNA was enhanced by Ang II with tempol and TNF- $\alpha$, suggesting that a possible regulatory mechanism of Ucn II may involve the NF- $\mathrm{B}$ pathway, i.e. inflammatory stress, because Ang II stimulates both oxidative stress and inflammatory stress (Luft 2002). A search for transcription factor binding motifs (Akiyama 1995) within the Ucn II promoter, using the UCSC Genome browser (Chen et al. 2003, Kent et al 2002, Karolchik et al. 2003), also supported the potential involvement of activated NF- $\kappa B$ in the transcription of Ucn II mRNA. The NF- $\kappa \mathrm{B}$ binding motif, however, has not been shown in the mouse Ucn I promoter region (Zhao et al. 1998). Furthermore, our results on the expression of Ucn II mRNA by co-incubation with TNF- $\alpha$ and potential inhibitors, such as erythromycin and PDTC (Sherman et al. 1993), supports our hypothesis that the regulation of Ucn II mRNA by TNF- $\alpha$ may be mediated by the NF-кB pathway, i.e. Ucn II mRNA expression may be induced by inflammatory stress rather than by oxidative stress. Although erythromycin has miscellaneous actions, such as antibiotic and anti-oxidative actions, it is reported that erythromycin also has the inhibitory properties of NF- $\kappa \mathrm{B}$ signaling in addition to such actions (Desaki et al. 2004, Yasutomi et al. 2005), therefore, suppression of TNF- $\alpha$-induced increase in Ucn II mRNA by erythromycin may be, at least in part, attributed to the inhibition of NF- $\mathrm{BB}$ signaling. The results on the expression pattern of Ucn I and Ucn II mRNA by Ang II may also indicate that the expression of Ucn I mRNA may be relatively dominant in HL-1 cardiomyocytes and these peptides may 

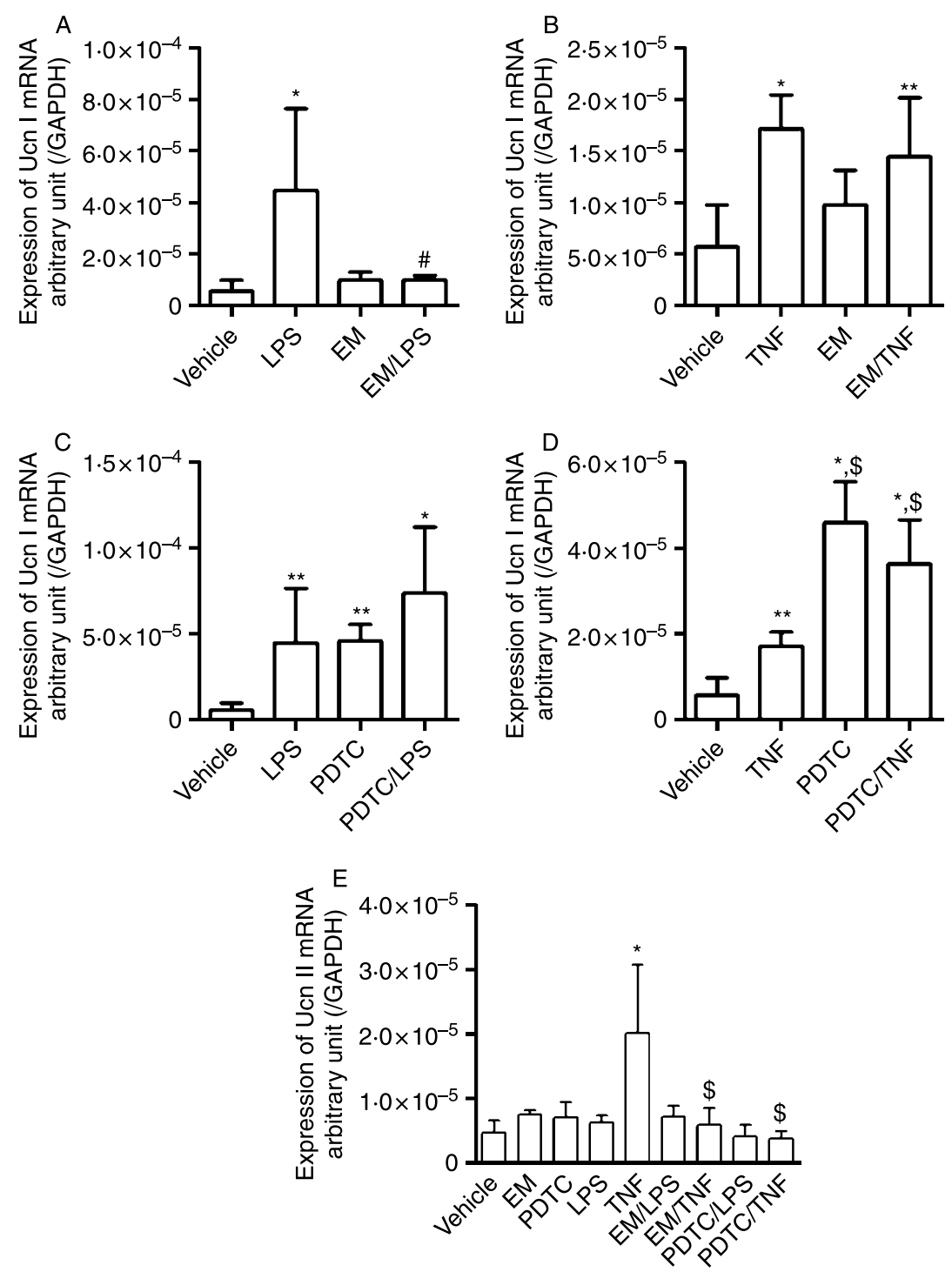

Figure 7 The effects of erythromycin (EM) and ammonium pyrrolidinedithiocarbamate (PDTC) on LPS- or TNF- $\alpha$-induced expression of Ucn I (A-D) and Ucn II (E) mRNAs at $3 \mathrm{~h}$. Erythromycin abolished increase in Ucn I mRNA, but not by TNF- $\alpha$ (A and B), but PDTC increased expression of Ucn I mRNA (C and D). Ucn II mRNA was regulated by TNF- $\alpha$, but not by LPS, and TNF- $\alpha$-induced increase in Ucn II mRNA was suppressed by erythromycin and PDTC, indicating that Ucn II mRNA may be regulated by nuclear factor- $\kappa$ B. Data are presented as the mean \pm s.D. LPS, LPS $1 \mathrm{ng} / \mathrm{ml}$, TNF, TNF- $\alpha$ $10 \mathrm{ng} / \mathrm{ml}$, EM, erythromycin $10^{-5} \mathrm{~mol} / \mathrm{l}$, PDTC, PDTC $10^{-4} \mathrm{~mol} / \mathrm{l},{ }^{*} P<0.01$ versus vehicle, ${ }^{* \star} P<0.05$ versus vehicle, $\# P<0.01$ versus LPS, $\$ P<0.01$ versus TNF.

negatively regulate in each other. Taken together, the present results suggest that Ucn I mRNA and Ucn II mRNA are differentially regulated, i.e. NF- $\kappa \mathrm{B}$ may, at least in part, be involved in the regulation of Ucn II mRNA, while oxidative stress may up-regulate Ucn I mRNA in HL-1 cardiomyocytes. These data also suggest that Ucn I and Ucn II may play a pathophysiological role in cardiac disease, especially in heart failure, in which the levels of vasoactive substances such as cytokines and Ang II (Matsumori et al. 1994, Ikeda et al. 2008) are increased.

In conclusion, the present results demonstrate that HL-1 cardiomyocytes contain the Ucn-CRH receptor system, which may be regulated by two major forms of cardiac stress, oxidative and inflammatory stress. In heart disease, such differential regulation of Ucn I and Ucn II could play a critical role in stress adaptation via the Ucn-CRH receptor system. 

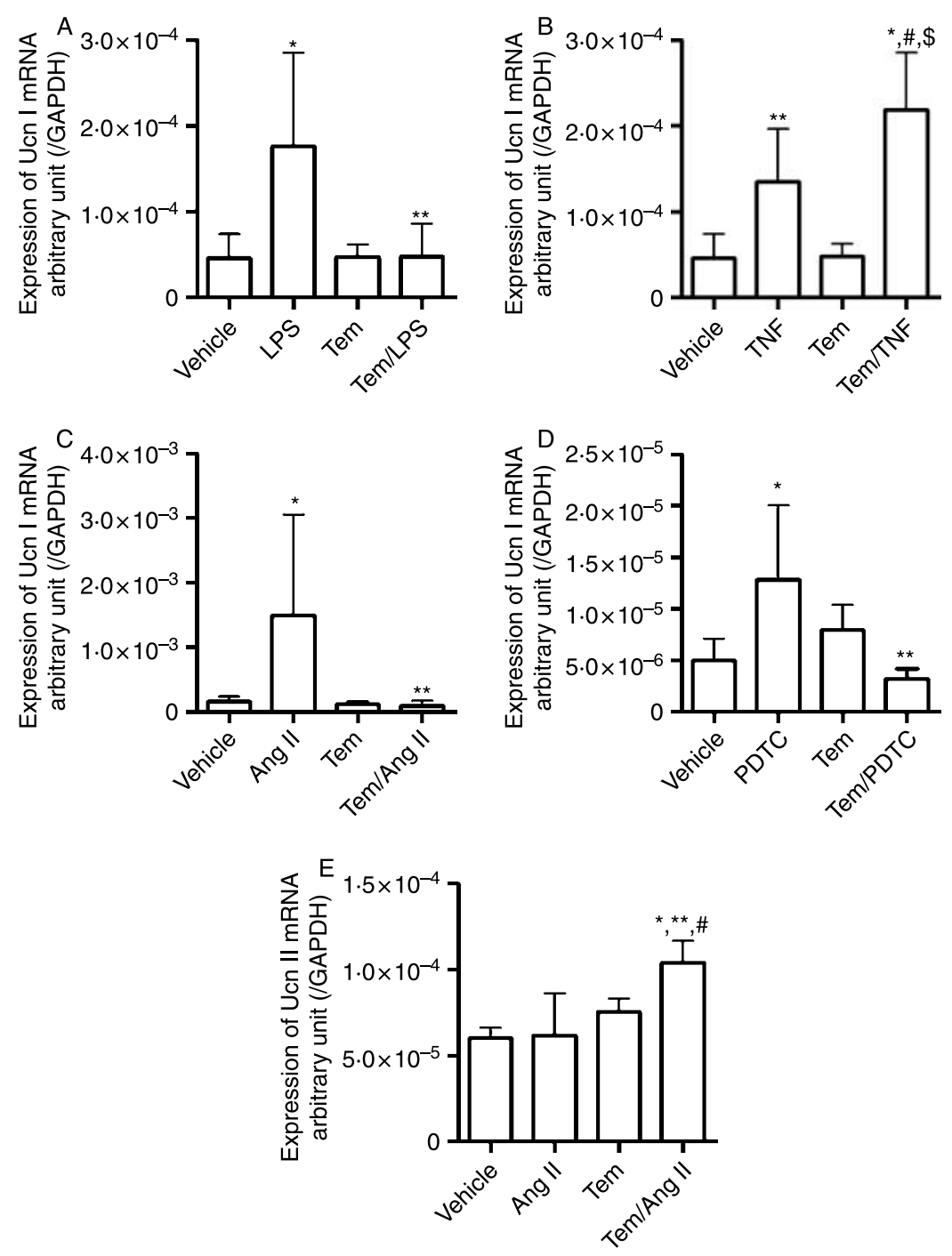

Figure 8 The effects of tempol on the regulation of Ucn I mRNA induced by LPS (A), TNF- $\alpha$ (B), Ang II (C), and ammonium pyrrolidinedithiocarbamate (PDTC) (D) and on Ucn II mRNA induced by Ang II (E) at $3 \mathrm{~h}$. Tempol abolished the LPS- and Ang II-induced expression of Ucn I mRNA, indicating that Ucn I mRNA may be dominantly regulated by oxidative stress. On the contrary, co-incubation with Ang II and tempol resulted in an increase in Ucn II mRNA expression. Data are represented as the mean \pm s.D. LPS, LPS $1 \mathrm{ng} / \mathrm{ml}$, TNF, TNF- $\alpha 10 \mathrm{ng} / \mathrm{ml}$, Ang II, Ang II $10^{-7} \mathrm{~mol} / \mathrm{l}$, PDTC, PDTC $10^{-4} \mathrm{~mol} / \mathrm{l}$, Tem, Tempol $10^{-4} \mathrm{~mol} / \mathrm{l},(\mathrm{A}){ }^{\star} P<0.01$ versus vehicle, ${ }^{\star \star} P<0.01$ versus $L P S$, (B) ${ }^{\star} P<0.01$ versus vehicle, ${ }^{\star \star} P<0.05$ versus vehicle, $\# P<0.05$ versus TNF, $\$ P<0.01$ versus Tem, (C) ${ }^{\star} P<0.05$ versus vehicle, ${ }^{\star \star} P<0.05$ versus Ang II, (D) ${ }^{\star} P<0.05$ versus vehicle, ${ }^{\star \star} P<0.05$ versus PDTC, (E) ${ }^{*} P<0.01$ versus vehicle, ${ }^{\star \star} P<0.01$ versus Ang II, $\# P<0.05$ versus Tem.

\section{Declaration of interest}

The authors declare that there is no conflict of interest that could be perceived as prejudicing the impartiality of the research reported.

\section{Funding}

This work was supported by The Jikei University Research Fund.

\section{References}

Akiyama Y 1995 TFSEARCH: searching transcription factor binding sites. Real World Computing Partnership, Japan (http://www. cbrc.jp/research/db/TFSEARCHJ.html).

Asaba K, Makino S, Nishiyama M \& Hashimoto K 2000 Regulation of type-2 corticotropin-releasing hormone receptor mRNA in rat heart by glucocorticoids and urocortin. Journal of Cardiovascular Pharmacology 36 493-497. 
Boyd JH, Mathur S, Wang Y, Bateman RM \& Walley KR 2006 Tolllike receptor stimulation in cardiomyoctes decreases contractility and initiates an NF- $\mathrm{B}$ dependent inflammatory response. Cardiovascular Research 72 384-393.

Brar BK, Chen A, Perrin MH \& Vale W 2004a Specificity and regulation of extracellularly regulated kinase $1 / 2$ phosphorylation through corticotropin-releasing factor (CRF) receptors 1 and $2 \beta$ by the CRF/urocortin family of peptides. Endocrinology 145 $1718-1729$

Brar BK, Jonassen AK, Egorina EM, Chen A, Negro A, Perrin MH, Mjøs OD, Latchman DS, Lee KF \& Vale W $2004 b$ Urocortin-II and urocortin-III are cardioprotective against ischemia reperfusion injury: an essential endogenous cardioprotective role for corticotropin releasing factor receptor type 2 in the murine heart. Endocrinology 145 24-35; discussion 21-23.

Chen A, Vaughan J \& Vale WW 2003 Glucocorticoids regulate the expression of the mouse urocortin II gene: a putative connection between the corticotropin-releasing factor receptor pathways. Molecular Endocrinology 17 1622-1639.

Claycomb WC, Lanson NA Jr, Stallworth BS, Egeland DB, Delcarpio JB, Bahinski A \& Izzo NJ Jr 1998 HL-1 cells: a cardiac muscle cell line that contracts and retains phenotypic characteristics of the adult cardiomyocyte. PNAS 95 2979-2984.

Coste SC, Kesterson RA, Heldwein KA, Stevens SL, Heard AD, Hollis JH, Murray SE, Hill JK, Pantely GA, Hohimer AR et al. 2000 Abnormal adaptations to stress and impaired cardiovascular function in mice lacking corticotropin-releasing hormone receptor-2. Nature Genetics 24 403-409.

Coste SC, Heldwein KA, Stevens SL, Tobar-Dupres E \& Stenzel-Poore MP 2001 IL- $1 \alpha$ and TNF $\alpha$ down-regulate CRH receptor-2 mRNA expression in the mouse heart. Endocrinology 142 3537-3545.

Desaki M, Okazaki H, Sunazuka T, Omura S, Yamamoto K \& Takizawa H 2004 Molecular mechanisms of anti-inflammatory action of erythromycin in human bronchial epithelial cells: possible role in the signaling pathway that regulates nuclear factor- $\mathrm{B}$ activation. Antimicrobial Agents and Chemotherapy $\mathbf{4 8}$ $1581-1585$

Hailman E, Lichenstein HS, Wurfel MM, Miller DS, Johnson DA, Kelley M, Busse LA, Zukowski MM \& Wright SD 1994 Lipopolysaccharide (LPS)-binding protein accelerates the binding of LPS to CD14. Journal of Experimental Medicine $\mathbf{1 7 9}$ 269-277.

Heldwein KA, Duncan JE, Stenzel P, Rittenberg MB \& Stenzel-Poore MP 1997 Endotoxin regulates corticotropin-releasing hormone receptor 2 in heart and skeletal muscle. Molecular and Cellular Endocrinology 131 167-172.

Honjo T, Inoue N, Shiraki R, Kobayashi S, Otsui K, Takahashi M, Hirata K, Kawashima S, Yokozaki H \& Yokoyama M 2006 Endothelial urocortin has potent antioxidative properties and is upregulated by inflammatory cytokines and pitavastatin. Journal of Vascular Research 43 131-138.

Ikeda K, Tojo K, Sato S, Ebisawa T, Tokudome G, Hosoya T, Harada M, Nakagawa O \& Nakao K 1998 Urocortin, a newly identified corticotropin-releasing factor-related mammalian peptide, stimulates atrial natriuretic peptide and brain natriuretic peptide secretions from neonatal rat cardiomyocytes. Biochemical and Biophysical Research Communications 250 298-304.

Ikeda K, Tojo K, Tokudome G, Hosoya T, Tajima N, Oki Y, Asaba K, Hashimoto K, Harada M \& Nako K 2001 Urocortin is an endogenous cardioprotective factor against negative effects of cytokines in the heart. Program of the 83rd Annual Meeting of The Endocrine Society, Denver, CO, p 419 (Abstract).

Ikeda K, Tojo K, Oki Y \& Nakao K 2002 Urocortin has cell-proliferative effects on cardiac non-myocytes. Life Sciences 71 1929-1938.

Ikeda K, Tojo K, Tokudome G, Ohta M, Sugimoto K, Tamura T, Tajima N, Mochizuki S, Kawakami M \& Hosoya T 2003 Cardiac expression of urocortin (Ucn) in diseased heart; preliminary results on possible involvement of $\mathrm{Ucn}$ in pathophysiology of cardiac diseases. Molecular and Cellular Biochemistry 252 25-32.

Ikeda K, Tojo K, Otsubo C, Udagawa T, Hosoya T, Tajima N, Nakao K \& Kawamura M $2005 a$ Effects of urocortin II on neonatal rat cardiac myocytes and non-myocytes. Peptides 26 2473-2481.

Ikeda K, Tojo K, Otsubo C, Udagawa T, Kumazawa K, Ishikawa M, Tokudome G, Hosoya T, Tajima N, Claycomb WC et al. $2005 b$ 5-Hydroxytryptamine synthesis in HL-1 cells and neonatal rat cardiocytes. Biochemical and Biophysical Research Communications 328 $522-525$.

Ikeda K, Tojo K, Udagawa T, Otsubo C, Ishikawa M, Tokudome G, Hosoya T, Tajima N, Nakao K \& Kawamura M 2008 Cellular physiology of rat cardiac myocytes in cardiac fibrosis: in vitro simulation using the cardiac myocyte/cardiac non-myocyte co-culture system. Hypertension Research 31 693-706.

Jefferson KK, Smith MF Jr \& Bobak DA 1999 Roles of intracellular calcium and NF- $\mathrm{KB}$ in the Clostridium difficile toxin A-induced up-regulation and secretion of IL-8 from human monocytes. Journal of Immunology 163 5183-5191.

Karolchik D, Baertsch R, Diekhans M, Furey TS, Hinrichs A, Lu YT, Roskin KM, Schwartz M, Sugnet CW, Thomas DJ et al. 2003 The UCSC genome browser database. Nucleic Acids Research 31 $51-54$.

Kent WJ, Sugnet CW, Furey TS, Roskin KM, Pringle TH, Zahler AM \& Haussler D 2002 The human genome browser at UCSC. Genome Research 12 996-1006 (The software is available at http://genome. ucsc.edu/index.html?org).

Kimura Y, Takahashi K, Totsune K, Muramatsu Y, Kaneko C, Darnel AD, Suzuki T, Ebina M, Nukiwa T \& Sasano H 2002 Expression of urocortin and corticotropin-releasing factor receptor subtypes in the human heart. Journal of Clinical Endocrinology and Metabolism 87 340-346.

Li C, Chen P, Vaughan J, Blount A, Chen A, Jamieson PM, Rivier J, Smith MS \& Vale W 2003 Urocortin III is expressed in pancreatic $\beta$-cells and stimulates insulin and glucagon secretion. Endocrinology 144 3216-3224.

Livak KJ \& Schmittgen TD 2001 Analysis of relative gene expression data using real-time quantitative PCR and the $2^{-\Delta \Delta C_{(t)}}$ Method. Methods 25 402-408.

Luft FC 2002 Angiotensin II, the AT2 receptor, and nuclear factor-kB activation. Kidney International 61 2272-2273.

Matsumori A, Yamada T, Suzuki H, Matoba Y \& Sasayama S 1994 Increased circulating cytokines in patients with myocarditis and cardiomyopathy. British Heart Journal 72 561-566.

Miyachi Y, Yoshioka A, Imamura S \& Niwa Y 1986 Effect of antibiotics on the generation of reactive oxygen species. Journal of Investigative Dermatology 86 449-453.

Moss AC, Anton P, Savidge T, Newman P, Cheifetz AS, Gay J, Paraschos S, Winter MW, Moyer MP, Karalis K et al. 2007 Urocortin II mediates pro-inflammatory effects in human colonocytes via corticotropin-releasing hormone receptor $2 \alpha$. Gut 56 1210-1217.

Pañeda C, Winsky-Sommerer R, Boutrel B \& de Lecea L 2005 The corticotropin-releasing factor-hypocretin connection: implications in stress response and addiction. Drug News $\mathcal{E}$ Perspectives 18 $250-255$

Rozen S \& Skaletsky H 2000 Primer3 on the WWW for general users and for biologist programmers. In Bioinformatics Methods and Protocols: Methods in Molecular Biology, pp 365-386. Eds S Krawetz \& S Misener. Totowa: Humana Press (The software is available at http://frodo.wi.mit.edu/primer3/input.htm).

Saito T, Itoh H, Chun TH, Fukunaga Y, Yamashita J, Doi K, Tanaka T, Inoue M, Masatsugu K, Sawada N et al. 2001 Coordinate regulation of endothelin and adrenomedullin secretion by oxidative stress in endothelial cells. American Journal of Physiology. Heart and Circulatory Physiology 281 H1364-H1371. 
Sakai N, Mizuno R, Ono N, Kato H \& Ohhashi T 2007 High oxygen tension constricts epineurial arterioles of the rat sciatic nerve via reactive oxygen species. American Journal of Physiology. Heart and Circulatory Physiology 293 H1498-H1507.

Saruta M, Takahashi K, Suzuki T, Torii A, Kawakami M \& Sasano H 2004 Urocortin 1 in colonic mucosa in patients with ulcerative colitis. Journal of Clinical Endocrinology and Metabolism 89 5352-5361.

Sarzi-Puttini P, Atzeni F, Doria A, Iaccarino L \& Turiel M 2005 Tumor necrosis factor- $\alpha$, biologic agents and cardiovascular risk. Lupus $\mathbf{1 4}$ $780-784$.

Sassone-Corsi P 1998 Coupling gene expression to cAMP signalling: role of CREB and CREM. International Journal of Biochemistry and Cell Biology 30 27-38.

Sherman MP, Aeberhard EE, Wong VZ, Griscavage JM \& Ignarro LJ 1993 Pyrrolidine dithiocarbamate inhibits induction of nitric oxide synthase activity in rat alveolar macrophages. Biochemical and Biophysical Research Communications 191 1301-1308.

Smith PK, Krohn RI, Hermanson GT, Mallia AK, Gartner FH, Provenzano MD, Fujimoto EK, Goeke NM, Olson BJ \& Klenk DC 1985 Measurement of protein using bicinchoninic acid. Analytical Biochemistry 150 76-85.

Takahashi K, Totsune K, Murakami O, Saruta M, Nakabayashi M, Suzuki T, Sasano H \& Shibahara S 2004 Expression of urocortin III/stresscopin in human heart and kidney. Journal of Clinical Endocrinology and Metabolism 89 1897-1903.
Tu H, Kastin AJ, Bjorbaek C \& Pan W 2007 Urocortin trafficking in cerebral microvessel endothelial cells. Journal of Molecular Neuroscience 31 171-181.

Uzuki M, Sasano H, Muramatsu Y, Totsune K, Takahashi K, Oki Y, Iino K \& Sawai T 2001 Urocortin in the synovial tissue of patients with rheumatoid arthritis. Clinical Science 100 577-589.

Yasutomi M, Ohshima Y, Omata N, Yamada A, Iwasaki H, Urasaki Y \& Mayumi M 2005 Erythromycin differentially inhibits lipopolysaccharide- or poly(I:C)-induced but not peptidoglycan-induced activation of human monocyte-derived dendritic cells. Journal of Immunology 175 8069-8076.

Yuan H, Perry CN, Huang C, Iwai-Kanai E, Carreira RS, Glembotski CC \& Gottlieb RA 2009 LPS-induced autophagy is mediated by oxidative signaling in cardiomyocytes and is associated with cytoprotection. American Journal of Physiology. Heart and Circulatory Physiology 296 470-479.

Zhao L, Donaldson CJ, Smith GW \& Vale WW 1998 The structures of the mouse and human urocortin genes (Ucn and UCN). Genomics 50 23-33.

Received in final form 4 March 2009

Accepted 23 March 2009

Made available online as an Accepted Preprint 23 March 2009 